Acta Universitatis Lodziensis

www.czasopisma.uni.lodz.pl/foe/

4(336) 2018

DOI: http://dx.doi.org/10.18778/0208-6018.336.05

\title{
Katarzyna Zeug-Żebro
}

University of Economics in Katowice, Faculty of Management, Department of Statistics, Econometrics and Mathematics, katarzyna.zeug-zebro@ue.katowice.pl

\section{Monika Miśkiewicz-Nawrocka}

University of Economics in Katowice, Faculty of Management, Department of Statistics, Econometrics and Mathematics, monika.miskiewicz@ue.katowice.pl

\section{The Demographic Situation and the Level of Unemployment in Poland in the Years 2002, 2008 and 2014}

\begin{abstract}
The demographic changes occurring in Poland since the 1980s clearly show the aging of the population on which fertility, mortality and migration have a huge impact. This phenomenon is a serious demographic and socio-economic problem because it may lead to many adverse consequences, i.e. an increase in public expenditure, policy changes regarding the functioning of social security, health and education, increased demand for care services, a decrease in pension benefits and social benefits, the elongation of the retirement age, as well as an increase in unemployment and mass migration. In the study, we will carry out a spatial analysis of the demographic potential and the level of unemployment in Poland. In order to verify the hypothesis that the aging process of society negatively affects the level of unemployment, the relationship between the level of unemployment and the demographic potential in Poland in 2002, 2008 and 2014 will be examined.
\end{abstract}

Keywords: demographic potential, level of unemployment, Perkal synthetic indicator, spatial autocorrelation

JEL: C49 


\section{Introduction}

The phenomenon of population aging is a serious demographic and also socio-economic problem. The demographic changes observed since the 1980s in Poland show how significantly the age structure of Polish society has changed and is still changing. The following processes have a huge impact on the development of the phenomenon of population aging in Poland: fertility, mortality and migration. The progressive process of population aging may lead to many adverse consequences, e.g.: an increase in public expenditure, changes of rules regarding the functioning of social security, health and education systems, increased demand for care services, a decrease in pensions and social benefits, the elongation of the retirement age, as well as an increase in unemployment and mass migration.

Another important socio-economic problem is unemployment. The value of the unemployment rate which has been growing in Poland since 2009 is one of the most important and difficult to solve problems of the Polish economy. It stems, among others, from economic transformations, the increasing technical and organisational progress in the sphere of production, the collapse of entire industries, the lack of qualifications and work experience, as well as low mobility of the population, and the high cost of commuting. Due to the long-term nature of this phenomenon, a negative effect on the standard of living of the population, the dynamics of economic development and social moods can be observed.

The aim of the paper is to analyse the spatial differentiation of dynamics of population aging and the level of unemployment in counties in Poland as well as to study the relationship between the unemployment rate and the process of aging of Polish society. All calculations and maps were made using the statistical programme R CRAN and Microsoft Excel. The data were obtained from the Local Data Bank of the Central Statistical Office, 2002-2014.

\section{Demographic changes in Poland in the years 2002-2014}

A complete image of changes in the number and structure of the population of Polish society can be seen based on the observations of real growth of the population number and the following indicators: the total fertility rate and gross reproduction rate (since 1950, a decreasing trend can be observed for these indicators). In the period under consideration, i.e. in the years 2002-2014, the actual population growth in Poland was stable and fluctuated around 0. Since 1950, the high value of total fertility rate (equal to 3.705 ) gradually decreased and in the analysed period it stood on average at 1.294 . This means that over 60 years the number of chil- 
dren born per woman of childbearing age (15-49) decreased by 2.4. Similar conclusions can be drawn by observing the average number of female children born per woman that is currently of childbearing age, i.e. the gross reproduction rate. The low value of total fertility rate (less than 2.10) observed in the period 2002 2013 does not guarantee the replacement of generations (Miśkiewicz-Nawrocka, 2015: 34-58).

The most commonly used measures of describing the process of population aging are: the factor of demographic aging (Cieślak, 1992), the index of demographic aging (Długosz, 1998: 15-25), and the demographic load factor (Cieślak, 1992). The aging of the population in a certain period of time can be also assessed by the indicator of demographic aging proposed by Z. Długosz (1998: 15-25). The estimated values of the above-mentioned measures indicate the aging of Polish society in the period 2002-2014. This phenomenon is particularly clearly visible based on the increasing values of the index of demographic aging. The Lodzkie and Swietokrzyskie Voivodships are characterised by the largest percentage of elderly population in each year of the analysed period, which greatly exceeds the value of the measurement obtained for the whole country. In the Masovian, Silesian, Lubusz, Podlachian and Opole Voivodships, the progress of the process of demographic aging was also higher than in Poland. The lowest values of demographic aging factor were obtained for the Warmian-Masurian Voivodship. The highest increase in the percentage of elderly population in the years 2002-2014 was recorded for the Silesian and Opole Voivodships and the lowest for the Masovian Voivodship. The study shows that the most advanced development of the aging population phenomenon in the years 2002-2014 applies to the Silesian Voivodship, but over the analysed period it was experienced in every voivodship to some extent. Measures of population aging show the greatest progress of this process in the Lodzkie, Swietokrzyskie, Silesian and Opole Voivodships and the lowest in the Masovian and Warmian-Masurian Voivodships (Miśkiewicz-Nawrocka, 2015: 34-58).

\section{Perkal synthetic measure}

One method of assessing the potential of the studied phenomenon (the level of development of the region) is a taxonomic method - the Perkal method, which is based on the construction of synthetic measure $m_{i}$ (Parysek, Wojtasiewicz, 1979). This measure is based on the presentation of the variability of a group of traits in a set of different objects in one year.

A higher value of the synthetic indicator means a better position of the object in terms of its level of development. The Perkal indicator is estimated as the arithmetic mean of traits 


$$
m_{i}=\frac{1}{n} \sum_{j=1}^{n} x_{i j}^{\prime}, \quad i=1,2, \ldots, n,
$$

where:

$n$-the number of included features,

$x_{i j}^{\prime}$ - the standardised value of the $j$-th feature of the $i$-th object,

$$
\begin{gathered}
x_{i j}^{\prime}=\frac{x_{i j}-\bar{x}_{j}}{S_{j}} \text { when } x_{i j} \text { is the value of stimulant, } \\
x_{i j}^{\prime}=-\frac{x_{i j}-\bar{x}_{j}}{S_{j}} \text { when } x_{i j} \text { is the value of destimulant, }
\end{gathered}
$$

$x_{i j}$ - the original value of the $j$-th feature of the $i$-th object,

$\bar{x}_{j}$ - the arithmetic mean value of the $j$-th feature,

$S_{j}$ - the value of standard deviation of the $j$-th feature.

\section{Spatial statistics}

There are two types of indicators of spatial associations (ISA): global and local measures of autocorrelation. The global autocorrelation follows from the existence of correlations across the spatial unit test. The local measure shows spatial dependence between the variable and its neighbouring units in a particular location. The most commonly used global and local measures are: the Moran statistics I (Moran, 1950: 17-23) and the Geary statistics $C$ (Geary, 1954: 115-145; Anselin, 1995: 93-115). The spatial autocorrelation occurs when a certain phenomenon in a single spatial unit alters the probability of occurrence of this phenomenon in the neighbouring units (Bivand, 1980: 23-38). In general, a positive spatial autocorrelation occurs when we observe the accumulation, in terms of location, of high or low values of observed variables. In the case of negative autocorrelation, high values are adjacent to low, and low to high, creating a kind of checkerboard (Suchecki, 2010). The lack of spatial autocorrelation means spatial randomness, i.e. high and low values of observed variables are distributed independently.

\subsection{Global statistics}

The Moran statistics is one of the most widely used measures in the study of spatial autocorrelation. The global Moran's $I$ is defined as follows: 


$$
I=\frac{n \sum_{i=1}^{n} \sum_{j=1}^{n} w_{i j}\left(x_{i}-\bar{x}\right)\left(x_{j}-\bar{x}\right)}{\sum_{i=1}^{n} \sum_{j=1}^{n} w_{i j} \cdot \sum_{i=1}^{n}\left(x_{i}-\bar{x}\right)^{2}}=\frac{n}{S_{0}} \cdot \frac{z^{T} W z}{z^{T} z}
$$

where: $x_{i}, x_{j}$ are the values of variables in the spatial unit $i$ and $j, \bar{x}$ is the mean of the variable for all units, $n$ is the total number of spatial units that are included in the study, $S_{0}$ is the sum of all elements of a spatial weight matrix, $z$ is a column vector of elements $z_{i}=x_{i}-\bar{x}, W$ is the spatial weight matrix degree $n$, defining the structure of the neighbourhood, $w_{i j}$ is an element of weights matrix $W$ (Kopczewska, 2006). This statistic takes values ranging from $[-1,1]$ : positive, when tested objects are similar, negative, when there is no similarity between them, and approximately equal to 0 for a random distribution of objects.

Cliff and Ord (1973) have shown that the distribution of Moran statistics is asymptotically normal. Thus, the statistical significance of spatial autocorrelation can be verified using normalised statistics $I^{S} \sim N(0,1)$ :

$$
I^{S}=\frac{I-E(I)}{\sqrt{\operatorname{Var}(I)}}
$$

where: $E(I)$ is the expected value of Moran's and $\operatorname{Var}(I)$ is its variance:

$$
\begin{gathered}
\mathrm{E}(I)=-\frac{1}{n-1}, \operatorname{Var}(I)=\frac{n^{2} S_{1}-n S_{2}+3 S_{0}^{2}}{\left(n^{2}-1\right) S_{0}^{2}}-\frac{1}{(n-1)^{2}} \\
S_{0}=\sum_{i=1}^{n} \sum_{j=1}^{n} w_{i j}, S_{1}=\frac{1}{2} \sum_{i=1}^{n} \sum_{j=1}^{n}\left(w_{i j}+w_{j i}\right)^{2}, S_{2}=\sum_{i=1}^{n}\left(\sum_{j=1}^{n} w_{i j}+\sum_{j=1}^{n} w_{j i}\right)^{2} .
\end{gathered}
$$

If the Moran statistic has a value $I \approx-(n-1)^{-1}, I^{S} \approx 0$, it indicates a random spatial pattern. However, when $I>-(n-1)^{-1}, I^{S}>0$, the spatialautocorrelation is positive, and if $I<-(n-1)^{-1}, I^{S}<0$, the spatial autocorrelation is negative.

\subsection{Local statistics}

The local Moran determines clusters of spatial units and verifies whether the unit is surrounded by neighbouring units with similar or different values of the variable studied in relation to the random distribution of these values in the studied space (Zeug-Żebro, Wolny-Dominiak, 2012: 992-998). 
In the case of non-standardised values of the variable and row-standardised spatial weight matrix (Arbia, 2006) $\left(\sum_{i=1}^{n} \sum_{j=1}^{n} w_{i j}=n\right)$ the local Moran is given by:

$$
I_{i}=\left[\left(x_{i}-\bar{x}\right) \sum_{j=1}^{n} w_{i j}\left(x_{j}-\bar{x}\right)\right] /\left[\sum_{i=1}^{n} \frac{\left(x_{i}-\bar{x}\right)^{2}}{n}\right],
$$

where all the elements of the formula are defined as in the global Moran's $I$. The standardised local Moran's $I_{i}^{S}$ is used to test the statistical significance of local spatial autocorrelation (Anselin, 1995: 93-115):

$$
I_{i}^{S}=\frac{I_{i}-\mathrm{E}\left(I_{i}\right)}{\sqrt{\operatorname{Var}\left(I_{i}\right)}} \sim N(0,1)
$$

where: $E\left(I_{i}\right)$ is the expected value of the local Moran and $\operatorname{Var}\left(I_{i}\right)$. is its variance

$$
\mathrm{E}\left(I_{i}\right)=-\frac{\sum_{j=1}^{n} w_{i j}}{n-1} \mathrm{i} \operatorname{Var}\left(I_{i}\right)=\frac{(n-k) \sum_{i \neq j} w_{\mathrm{ij}}^{2}}{n-1}+\frac{2(2 k-n) \sum_{l \neq i} \sum_{\mathrm{hi \neq i}} w_{\mathrm{il}} w_{\mathrm{ih}}}{(n-1)(n-2)}-\left(\frac{-\sum_{i \neq j} w_{\mathrm{ij}}}{n-1}\right)^{2},(
$$

where $k=\left(\frac{1}{n} \sum_{i}\left(x_{i}-\bar{x}\right)^{4}\right) /\left(\frac{1}{n} \sum_{i}\left(x_{i}-\bar{x}\right)^{2}\right)^{2}$.

When $I_{i}^{S}$ is negative, the spatial autocorrelation is negative, too, i.e. when the object is surrounded by spatial units with significantly different values of the studied variable. The spatial autocorrelation is positive when $I_{i}^{S}>0$, the object is surrounded by similar neighbouring units.

\section{The empirical analysis}

All the Polish counties in 2002, 2008 and 2014 were the object of the study. In the first stage of the study, a Perkal synthetic measure was estimated and the counties were sorted due to the level of the studied phenomenon, i.e. the process of society aging. Table 1 shows a set of diagnostic features taken into account in the study, assuming the division between stimulants (S) and destimulants (D) ${ }^{1}$. The selection of these variables resulted from the analysis of the factors determining the process of demographic change.

${ }^{1}$ The division of diagnostic features was based on the correlation coefficient calculated between the variables and the index of demographic aging. 
Table 1. Set of diagnostic variables

\begin{tabular}{|l|l|c|}
\hline X1 & Average life expectancy for men aged 0 [years] & S \\
\hline X2 & Average life expectancy for men aged 0 [years] & S \\
\hline X3 & $\begin{array}{l}\text { Demographic dependency ratio - the population of non-working age per 100 persons } \\
\text { of working age [person] }\end{array}$ & D \\
\hline X4 & $\begin{array}{l}\text { Demographic dependency ratio - the population of post-production age per 100 per- } \\
\text { sons of pre-production age [person] }\end{array}$ & D \\
\hline X5 & $\begin{array}{l}\text { Demographic dependency ratio - the population of post-production age per 100 per- } \\
\text { sons of working age [person] }\end{array}$ & D \\
\hline X6 & Natural movement - the number of live births per 1000 population & S \\
\hline
\end{tabular}

Source: own elaboration

Table 2. The Polish counties for which the Perkal indicator reached 10 smallest and largest values in the years 2002, 2008 and 2014

\begin{tabular}{|c|c|c|c|c|c|}
\hline \multicolumn{2}{|c|}{2002} & \multicolumn{2}{|c|}{2008} & \multicolumn{2}{|c|}{2014} \\
\hline $\max$ & $\min$ & $\max$ & $\min$ & $\max$ & $\min$ \\
\hline Warsaw & Zory & Sopot & Zory & chojnicki & $\begin{array}{l}\text { nowodworski } \\
\text { (Pomeranian) }\end{array}$ \\
\hline Sopot & braniewski & Warszawa & kartuski & Lodz & $\begin{array}{l}\text { grodziski } \\
\text { (Greater } \\
\text { Poland) }\end{array}$ \\
\hline Lodz & bytowski & Lodz & slupski & Warsaw & kartuski \\
\hline hajnowski & slupski & Katowice & $\begin{array}{l}\text { grodziski } \\
\text { (Greater } \\
\text { Poland) }\end{array}$ & Katowice & bytowski \\
\hline Katowice & olsztynski & hajnowski & torunski & hajnowski & pszczynski \\
\hline Poznan & $\begin{array}{l}\text { nowodworski } \\
\text { (Pomeranian) }\end{array}$ & Chorzow & wejherowski & Sopot & Bydgoszcz \\
\hline Chorzow & wejherowski & $\begin{array}{l}\text { bielski } \\
\text { (Podlachian) }\end{array}$ & obornicki & Jelenia Gora & leborski \\
\hline Cracow & wolsztynski & Cracow & gdanski & JastrzebieZdroj & nowosadecki \\
\hline Jelenia Gora & gdanski & Poznan & bytowski & Kalisz & koszalinski \\
\hline $\begin{array}{l}\text { bielski } \\
\text { (Podlachian) }\end{array}$ & glogowski & Gdansk & grudziadzki & Sosnowiec & limanowski \\
\hline
\end{tabular}

Source: own elaboration

In order to eliminate variables strongly correlated with other features, the parametric method proposed by Z. Hellwig (1981: 46-68) was used. Because only variables X4 and X5 (in 2014) proved to be strongly correlated, all of the variables listed in Table 1 were taken into account as a set of diagnostic features in the years 2002, 2008 and 2014. In the next step of the study, a Perkal synthetic measure was used to order the Polish counties due to the level of phenomenon of aging population. Table 2 shows the counties for which the Perkal indicator was the biggest and the smallest in the years 2002, 2008 and 2014. 
Based on the estimated values of the Perkal indicator, it can be concluded that the most advanced aging of the population (the first 10 positions in the ranking) in the analysed period occurred in Warsaw, Sopot, Lodz and Katowice and the hojnowski county. The most favourable situation can be noted in the counties of Zory and Slupsk, Wejherowo, Nowy Dwor, Gdansk, and Grodzisk, which in the years 2002, 2008 and 2014 occupied the last positions in the ranking.

Analysing the dynamics of population aging in the years 2002-2014, it can be seen that the greatest favourable changes (a decrease of approximately 320-260 positions) were recorded in the counties of Bydgoszcz, Gdansk, Slupsk, Olsztyn, and the least favourable changes in the ranking (an increase of about 220 positions) apply to the milicki, kwidzynski, bydgoski, Jastrzebie Zdroj and elcki counties. The smallest change in positions in the ranking in $2014 \mathrm{com}-$ pared to 2002 can be observed in the following counties: brzezinski (a decrease of 3 positions), opoczynski (an increase of 3 positions), ciechanowski (position unchanged), the Capital City of Warsaw (an increase of 2 positions), wyszkowski (an increase of 2 positions), zurominski (an increase of 1 position), gliwicki (an increase of 3 positions), Czestochowa (an increase of 1 position), Jaworzno (a decrease of 1 position), Katowice (a decrease of 1 position), zawiercianski (a decrease of 1 position), janowski (a decrease of 1 position), lukowski (an increase of 2 positions), jaroslawski (a decrease of 2 positions), ropczycko-sedziszowskim (a decrease of 3 positions), hajnowski (an increase of 1 position), slupecki (a decrease of 3 positions), policki (a decrease of 1 position), Jelenia Gora (a decrease of 2 positions), sredzki (a decrease of 3 positions), and oleski (an increase of 1 position). Moreover, in 2014, compared to 2008, the counties of Warszawa, Czestochowa, Katowice and the jaroslawski, hajnowski, slupecki, policki counties were characterised by a stable situation (changes of 2-3 positions) in the ranking.

In order to compare the Polish counties in terms of the development level of their aging population and unemployment, average monthly unemployment rates in the counties in 2002, 2008 and 2014 were estimated. Table 3 shows the counties for which the average monthly unemployment rates were the biggest and the smallest in those years.

On the basis of data in Table 3, it can be concluded that the highest unemployment rates (the first 10 positions in the ranking) in the years 2002, 2008 and 2014 were recorded in the following counties: wejherowski, policki, ketrzynski, opolski, starogardzki and zninski. The most favourable situation (the lowest unemployment rate) can be noted in the following counties: Swinoujscie, Jaworzno, Koszalin, ostrowiecki, ostrowski, polkowicki, siedlecki, wyszkowski and ząbkowicki, which in the analysed period occupied the last 10 positions in the ranking. The zarski county is characterised by the biggest change, as it had one of the lowest unemployment rates in 2002 and one of the highest in the years 2008 and 2014. 
Table 3. The Polish counties for which the unemployment rate reached 10 smallest and largest values in the years 2002, 2008 and 2014

\begin{tabular}{|c|c|c|c|c|c|}
\hline \multicolumn{2}{|c|}{2002} & \multicolumn{2}{|c|}{2008} & \multicolumn{2}{|c|}{2014} \\
\hline $\max$ & $\min$ & $\max$ & $\min$ & $\max$ & $\min$ \\
\hline ketrzynski & siedlecki & zarski & Swinoujscie & zarski & polkowicki \\
\hline koscierski & zarski & zninski & siedlecki & starogardzki & Jaworzno \\
\hline $\begin{array}{l}\text { opolski } \\
\text { (Lublin) }\end{array}$ & wagrowiecki & bytowski & wyszkowski & bytowski & siedlecki \\
\hline szczycienski & polkowicki & wejherowski & Koszalin & leborski & zabkowicki \\
\hline wejherowski & Jaworzno & tczewski & polkowicki & sulecinski & glogowski \\
\hline policki & Swinoujscie & sulecinski & ostrowiecki & tczewski & wyszkowski \\
\hline braniewski & gorzowski & starogardzki & lobeski & zninski & otwocki \\
\hline zninski & Koszalin & stalowowolski & otwocki & wejherowski & \begin{tabular}{|l|}
$\begin{array}{l}\text { kedzierzyn- } \\
\text { sko-kozielski }\end{array}$ \\
\end{tabular} \\
\hline bialostocki & skierniewicki & ketrzynski & Jaworzno & policki & Swinoujscie \\
\hline szczecinecki & ostrzeszowski & szczycienski & zabkowicki & \begin{tabular}{|l|}
$\begin{array}{l}\text { opolski } \\
\text { (Lublin) }\end{array}$ \\
\end{tabular} & ostrowiecki \\
\hline
\end{tabular}

Source: own elaboration

Analysing the dynamics of unemployment rates in the years 2002-2014, it can be seen that the greatest favourable changes (a decrease of about 200 positions in the ranking) was recorded in the following counties: zlotoryjski, zaganski, krosnienski, ostrowiecki and kwidzynski. On the other hand, the least favourable changes were observed in the zarski county (an increase of 374 positions in the ranking) and the sulecinski and pinczowski counties (an increase of 300 positions in the ranking). The smallest changes in positions in the ranking in 2014 compared to 2002 can be observed in the following counties: laski (a decrease of 2 positions), lowicki (a decrease of 2 positions), wieruszowski (a decrease of 3 positions), grojecki (a decrease of 2 positions), siedlecki (an increase of 2 positions), bedzinski (an increase of 1 position), czestochowski (unchanged), Jaworzno (a decrease of 3 positions), Zory (an increase of 1 position), radzynski (unchanged), nowosolski (an increase of 1 position), nowotomyski (a decrease of 3 positions), Swinoujscie (an increase of 3 positions), policki (a decrease of 3 positions), polkowicki (a decrease of 3 positions), nyski (a decrease of 1 position), zninski (an increase of 1 position) wejherowski (a decrease of 3 positions), bartoszycki (a decrease of 2 positions), and ilawski (a decrease of 1 positions). Moreover, in 2014, compared to 2008, the counties of Siedlce, Gliwice, Polkowice as well as the wejherowski, bartoszycki counties were characterised by a stable situation (changes of 2-3 positions) in the ranking.

The spatial relationship between the unemployment rate and the advancement of population aging process on the basis of the estimated Perkal measure and the unemployment rates was examined by making a division of Polish counties into homogeneous groups based on the level of studied phenomena advancement. The 
total interval of measures variability was divided into four classes to which the counties were assigned according to the following rules (Kuc, 2012: 5-19; Zeliaś, 2000):

class I (high levels of the studied phenomenon): $\bar{m}+S_{m} \leq m_{i}$, class II (medium levels of the studied phenomenon): $\bar{m} \leq m_{i}<\bar{m}+S_{m}$, class III (low levels of the studied phenomenon): $\bar{m}-S_{m} \leq m_{i}<\bar{m}$, class IV (very low levels of the studied phenomenon): $m_{i}<\bar{m}-S_{m}$,

$$
\text { where: } \bar{m}=\frac{1}{n} \sum_{i=1}^{n} m_{i}, S_{m}=\sqrt{\frac{1}{n} \sum_{i=1}^{n}\left(m_{i}-\bar{m}\right)^{2}} \text {. }
$$

The results of the obtained spatial distribution of classes for the Polish territorial division into counties in 2002, 2008, 2014 are shown in the following maps (Figure 1). Maps (a), (c) and (e) show a breakdown due to the level of population aging expressed by the Perkal synthetic measure, and maps (b), (d) and (f) - due to the unemployment rate.
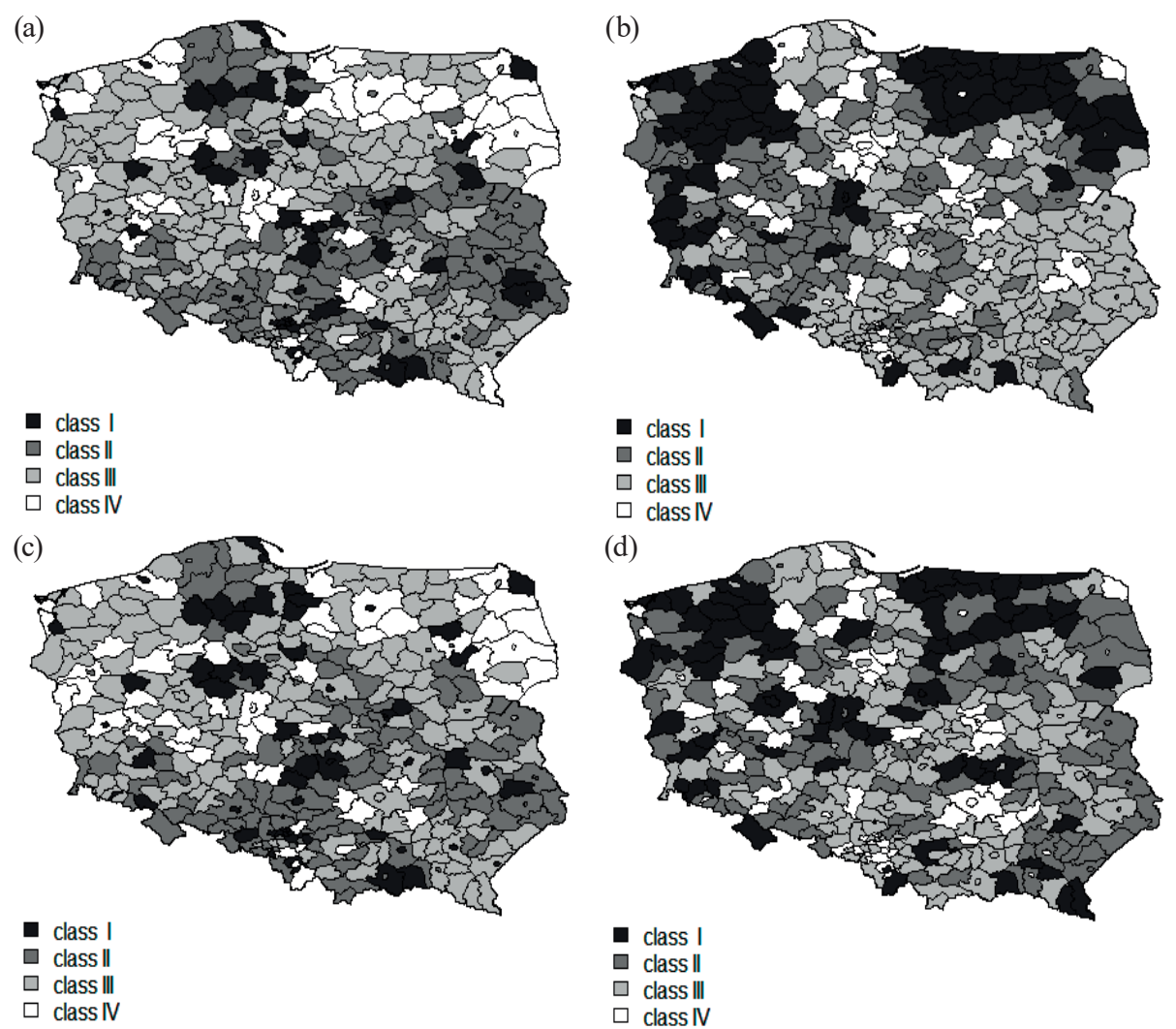

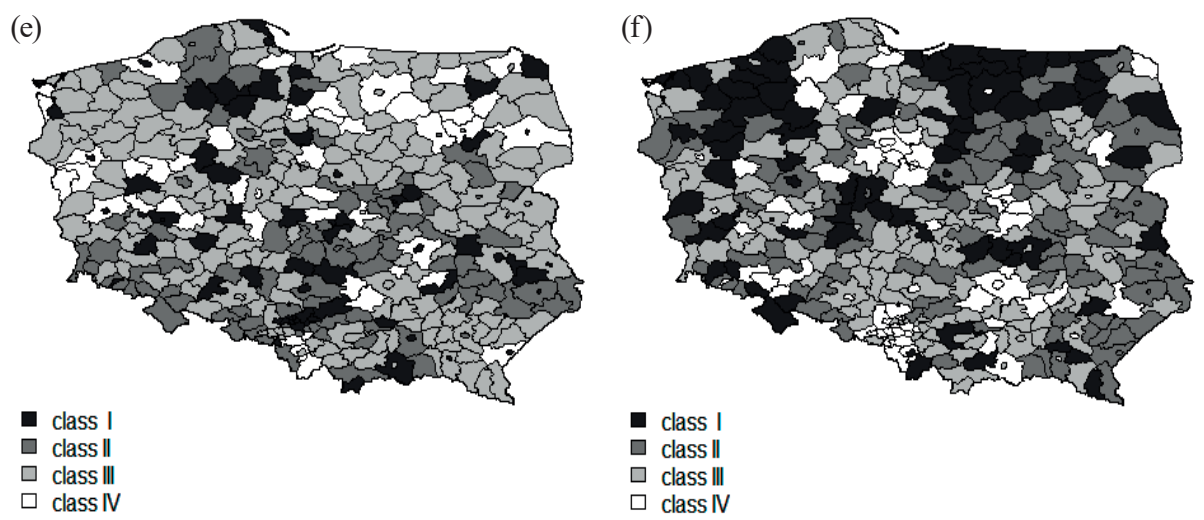

Figure 1. The classification of the Polish counties due to the value of the Perkal synthetic measure in the years: (a) 2002, (c), 2008 (e) 2014 and of the unemployment rate in the years:

(b) 2002, (d), 2008 (f) 2014

Source: own elaboration

Analysing these maps, it can be noted that in the years 2002, 2008 and 2014 most of the counties that belonged to the group I or II due to the value of unemployment rate were in the group IV or III due to the level of population aging process advancement. Similarly, most of the counties belonging to the group III or IV due to the value of unemployment rate were in the group I or II due to the level of population aging process advancement. This means that there is a correlation between the level of unemployment and the level of population aging advancement in the counties of Poland.

Spearman's correlation coefficients, which in the years 2002, 2008 and 2014 were respectively equal to $-0.44,-0.31$ and -0.23 , also indicate a negative correlation between the studied variables, i.e. the rate of unemployment and the advancement of population aging process. However, the strength of this correlation is weak.

In the next stage, we examined the spatial autocorrelation of Polish society aging process and the level of unemployment expressed by the rate of unemployment. The calculated values of global Moran are presented in Tables 4 and 5.

Analysing the data contained in Tables 4 and 5, it can be concluded that the global Moran values are positive and statistically significant. This means the similarity of spatial units (counties) due to the level of advancement of population aging process and the unemployment rate.

Table 4. Global Moran for the Perkal indicator in the years 2002, 2008 and 2014

\begin{tabular}{|c|c|c|c|c|}
\hline Year & $\boldsymbol{I}$ & $\mathbf{E}(\boldsymbol{I})$ & $\operatorname{Var}(\boldsymbol{I})$ & $\boldsymbol{p}$-value \\
\hline 2002 & 0.2315 & -0.0027 & 0.0012 & $3.114 \cdot 10^{-12}$ \\
\hline 2008 & 0.1782 & -0.0027 & 0.0012 & $5.588 \cdot 10^{-8}$ \\
\hline 2014 & 0.1531 & -0.0027 & 0.0012 & $2.482 \cdot 10^{-6}$ \\
\hline
\end{tabular}

Source: own elaboration 
Table 5. Global Moran for the unemployment rate in the years 2002, 2008 and 2014

\begin{tabular}{|c|c|c|c|c|}
\hline Year & $\boldsymbol{I}$ & $\mathbf{E}(\boldsymbol{I})$ & $\boldsymbol{V a r}(\boldsymbol{I})$ & $\boldsymbol{p}$-value \\
\hline 2002 & 0.3861 & -0.0027 & 0.0012 & $2.2 \cdot 10^{-16}$ \\
\hline 2008 & 0.3032 & -0.0027 & 0.0012 & $2.2 \cdot 10^{-16}$ \\
\hline 2014 & 0.2880 & -0.0027 & 0.0012 & $2.2 \cdot 10^{-16}$ \\
\hline
\end{tabular}

Source: own elaboration

The next stage of research was to estimate the local Moran in order to identify the spatial structure. The results of spatial distribution for the Polish counties in the years 2002, 2008, 2014 are shown in the following maps (Figure 2).

On the basis of the above-presented maps (Figure 2), it can be seen that only some of the local Moran values are statistically significant. In the studied period, significant and positive values of local Moran were obtained for the Perkal measure only for 56 counties in 2002, 44 counties in 2008, 34 counties in 2014, and for the unemployment rate only for 64 counties in 2002, 59 counties in 2008, and 68 counties in 2014. This means that in the chosen years these counties were surrounded by counties with similar values of the studied synthetic variable expressing the level of aging population. Therefore, the above-mentioned counties were clusters.

The local Moran statistic is statistically significant and less than zero for the Perkal measure for 11 counties in 2002, 13 counties in 2008, 16 counties in 2014, and for the unemployment rate for 4 counties in 2002, 4 counties in 2008, and 7 counties in 2014. This means that in the chosen years these counties were local outliers, because they were surrounded by counties with a relatively lower level of population aging process advancement.

For other counties, the local Moran was statistically insignificant.

(a)

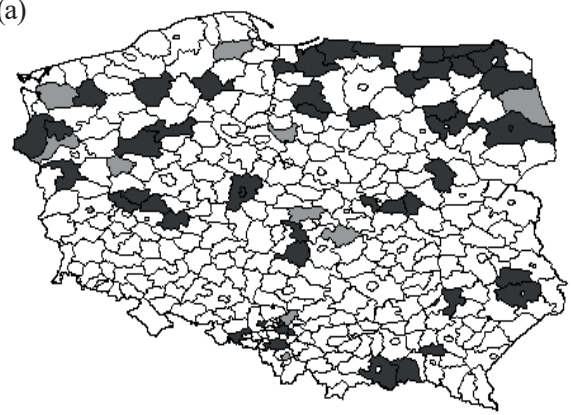

- $\mathrm{loc} M>0$

$\square$ locM insignificant

$\square$ locM $<0$ (b)

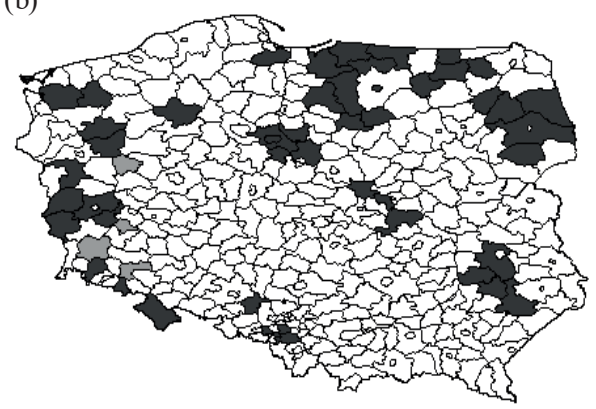

- locM>0

$\square$ locM insignificant

$\square$ loc $\mathrm{M}<0$ 


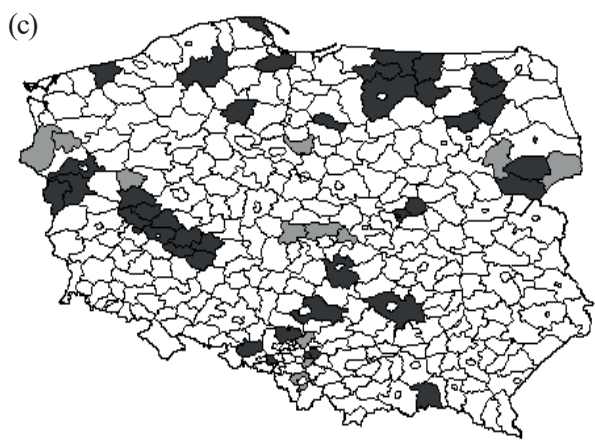

(d)

- $\quad \mathrm{oc} M>0$
$\square \quad$ locM insignificant
$\square \quad$ locM $<0$

(e)

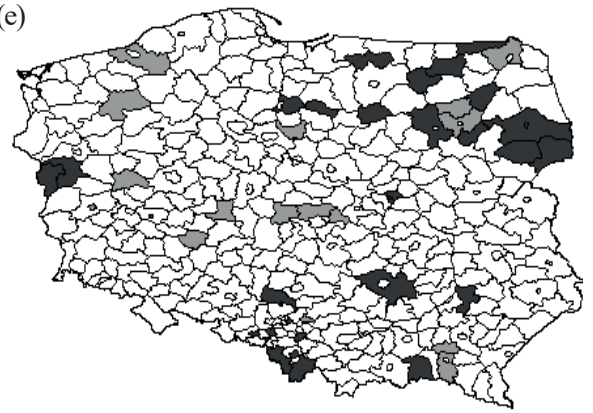

- $\mathrm{loc} M>0$

$\square$ locM insignificant

$\square$ loc $M<0$

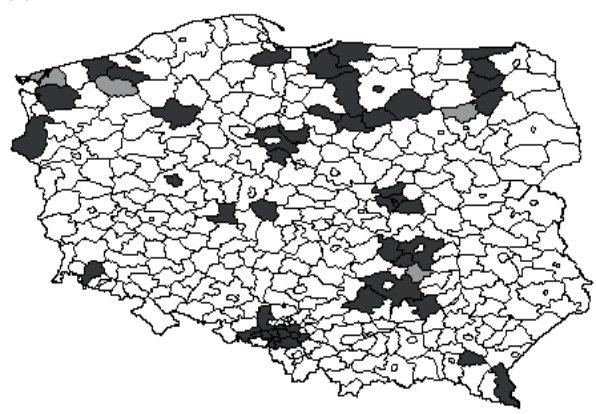
- $\mathrm{loc} M>0$
$\square$ locM insignificant
$\square$ loc $\mathrm{M}<0$

(f)

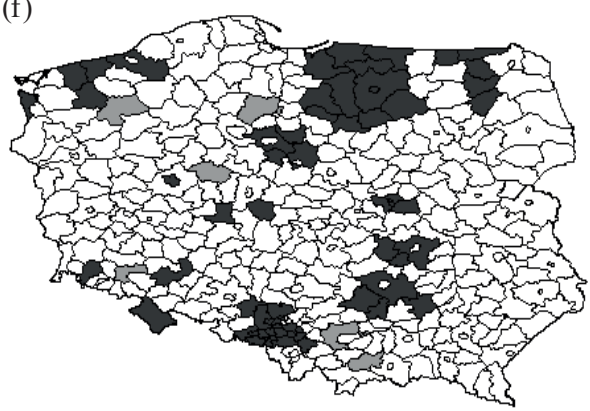

$\operatorname{loc} M>0$
$\operatorname{loc} M$ insignificant
$\operatorname{loc} M<0$

Figure 2. The classification of the Polish counties due to the value of the local Moran for the Perkal synthetic measure in the years: (a) 2002, (c) 2008, (e) in 2014 and for the unemployment rate in the years: (b) 2002, (d), 2008 (f) in 2014

Source: own elaboration

\section{Conclusions}

The study analysed the demographic situation and the level of unemployment in the counties of Poland and also researched the spatial correlation of these two phenomena. Based on the conducted research, it can be concluded that in the years 2002, 2008 and 2014 almost all of the counties were characterised by changes in the level of demographic potential and level of unemployment. The classification of counties due to the estimated Perkal measure and unemployment rate, has shown that there is a correlation between the level of unemployment and the level of population aging advancement in the Polish counties. Most of the counties for which the level of population aging advancement process was medium or high are 
characterised by low unemployment, and vice versa, while most of the counties for which the level of population aging advancement process was low or medium were characterised by high levels of unemployment.

The conducted analysis of spatial correlation of the demographic situation in the Polish counties based on local Moran statistics indicates the existence of positive and negative spatial autocorrelation, that is, the formation of territorial unit clusters with similar values of demographic potential level and outliers (i.e. counties surrounded by units of a relatively lower level of the studied phenomenon).

\section{References}

Anselin L. (1995), Local Indicators of Spatial Association - LISA, "Geographical Analysis", vol. 27, pp. $93-115$.

Arbia G. (2006), Spatial Econometrics: Statistical Foundations and Applications to Regional Growth Convergence, Springer, New York.

Bivand R. (1980), Autokorelacja przestrzenna a metody analizy statystycznej w geografii, [in:] Z. Chojnacki (ed.), Analiza regresji geografii, PWN, Poznań.

Cieślak M. (1992), Demografia. Metody analizy i prognozowania, Wydawnictwo Naukowe PWN, Warszawa.

Cliff A.D., Ord J.K. (1973), Spatial Autocorrelation, Pion, London.

Długosz Z. (1998), Próba określenia zmian starości demograficznej Polski w ujęciu przestrzennym, "Wiadomości Statystyczne", no. 3, pp. 15-25.

Geary R. (1954), The Contiguity Ratio and Statistical Mapping, "The Incorporated Statistician", vol. 5, pp. 115-145.

Hellwig Z. (1981), Wielowymiarowa analiza porównawcza i jej zastosowanie w badaniach wielocechowych obiektów gospodarczych, [in:] W. Welfe (ed.), Metody i modele ekonomiczno-matematyczne w doskonaleniu zarzadzania gospodarka socjalistyczna, PWE, Warszawa.

Kopczewska K. (2006), Ekonometria i statystyka przestrzenna z wykorzystaniem programu $R C R A N, \mathrm{CeDeWu}$, Warszawa.

Kuc M. (2012), The implementation of synthetic variable for constructing the standard of living measure in European Union countries, "Oeconomia Copernicana", no. 3, pp. 5-19.

Local Data Bank of the Central Statistical Office, bdl.stat.gov [accessed: 15.11.2016].

Miśkiewicz-Nawrocka M. (2015), Analiza porównawcza czynników wptywających na zmiany demograficzne w Polsce w latach 2002-2013, [in:] J. Mika, M. Miśkiewicz-Nawrocka (eds.), Metody i modele analiz ilościowych w ekonomii i zarządzaniu, część 7, Wydawnictwo Uniwersytetu Ekonomicznego w Katowicach, Katowice.

Moran P.A.P. (1950), Notes on Continuous Stochastic Phenomena, "Biometrika", vol. 37(1), pp. 17-23.

Parysek J.J., Wojtasiewicz L. (1979), Metody analizy regionalnej i metody planowania regionalnego, [w:] Studia KPZK PAN, t. LXIX, PWN, Warszawa.

Suchecki B. (ed.) (2010), Ekonometria przestrzenna. Metody i modele analizy danych przestrzennych, Wydawnictwo C.H. Beck, Warszawa.

Zeliaś A. (ed.) (2000), Taksonomiczna analiza przestrzennego zróżnicowania poziomu życia w Polsce w ujęciu dynamicznym, Wydawnictwo Akademii Ekonomicznej, Kraków.

Zeug-Żebro K., Wolny-Dominiak A. (2012), Spatial statistics in the analysis of county budget incomes in Poland with the R CRAN, [in:] J. Ramik, D. Stavárek (eds.), Proceedings of $30^{\text {th }} I n-$ ternational Conference Mathematical Methods in Economics, Silesian University, School of Business Administration, Karviná. 


\section{Sytuacja demograficzna a poziom bezrobocia w Polsce w latach 2002, 2008 i 2014}

Streszczenie: Zachodzące od lat osiemdziesiątych XX wieku zmiany demograficzne w Polsce uwidoczniają wyraźny proces starzenia się społeczeństwa, na który ogromny wpływ mają: rozrodczość, umieralność i migracja. Zjawisko to jest poważnym problemem demograficznym i społeczno-ekonomicznym, gdyż może prowadzić do wielu niekorzystnych konsekwencji, takich jak zwiększenie wydatków ze środków publicznych, zmiana zasad funkcjonowania systemów zabezpieczenia społecznego, opieki zdrowotnej i szkolnictwa, zwiększenie popytu na usługi opiekuńcze, obniżenie świadczeń emerytalno-rentowych oraz zasiłków socjalnych, wydłużenie wieku emerytalnego, wzrost stopy bezrobocia, masowa migracja zarobkowa. W artykule przeprowadzono analizę przestrzenną potencjału demograficznego oraz poziomu bezrobocia w Polsce. W celu weryfikacji hipotezy mówiącej, że proces starzenia się społeczeństwa negatywnie wpływa na poziom stopy bezrobocia, zbadano zależność między poziomem bezrobocia a potencjałem demograficznym Polski w latach 2002, 2008 i 2014.

Słowa kluczowe: potencjał demograficzny, poziom bezrobocia, syntetyczny wskaźnik Perkala, autokorelacja przestrzenna

JEL: C49

\begin{tabular}{|l|l|}
\hline \multirow{2}{*}{ OPEN ACCESS } & $\begin{array}{l}\text { C by the author, licensee Łódź University - Łódź University Press, Łódź, Poland. } \\
\text { This article is an open access article distributed under the terms and conditions } \\
\text { of the Creative Commons Attribution license CC-BY } \\
\text { (http: //creativecommons.org/licenses/by/3.0/) }\end{array}$ \\
\cline { 2 - 2 } & Received: 2016-12-18; verified: 2018-01-25. Accepted: 2018-03-29 \\
\hline
\end{tabular}

